\title{
First record of Peropteryx pallidoptera (Chiroptera: Emballonuridae) in Bolivia
}

\section{Primer registro de Peropteryx pallidoptera (Chiroptera: Emballonuridae) en Bolivia}

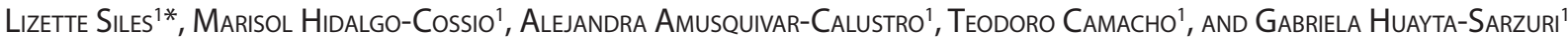 \\ 'Área de Mastozoología, Museo de Historia Natural Alcide d'Orbigny. Avenida Potosí 1458, Cochabamba. Cochabamba, Bolivia. E-mail: \\ liz.siles@gmail.com (LS), hidalgocossiomarisol@gmail.com (MH-C), ale.quivar@gmail.com (AA-C), teo.camacho.reyes@gmail.com (TC), \\ gabi.hs2016@gmail.com (GH-S). \\ *Corresponding author
}

\begin{abstract}
The genus Peropteryx contains five species distributed in the Neotropical region. Three of these species occur in Bolivia (P. macrotis, $P$. kappleri, and P. leucoptera). The recently described Peropteryx pallidoptera is distributed in the Amazonian lowland forests of Ecuador, Perú, Brazil, and Colombia. We report the first record of P. pallidoptera in Bolivia. On November 22, 2016, we observed a bat colony in a ground cavity, in a forest patch located in the rural community of Isinuta in Chapare Province (Cochabamba Department). The area is classified as southwestern Amazonian forests ecoregion. We collected one specimen and confirmed the identification of the species with skull measurements. We observed all external and cranial diagnostic characters of $P$. pallidoptera in our specimen. Also, the external and cranial measurements are within the range reported for the species. Our specimen extends the known distribution of $P$. pallidoptera 1,420 km to the southeast from the nearest point in Perú, and it is the southernmost locality for the species. The habitat type and roost where we collected P. pallidoptera is consistent with the descriptions in the literature. Our new record in Bolivia is within the potential wide distribution in the Amazon region predicted in the species description. However, it creates a large gap in northern Bolivia, northwestern Brazil, and southeastern Perú where more records should be expected in the future.
\end{abstract}

Key words: Amazonian region; Cochabamba; pale-winged doglike bat; range extension; southernmost record.

El género Peropteryx contiene cinco especies distribuidas en la región Neotropical. Tres de estas especies se encuentran en Bolivia ( $P$. macrotis, P. kappleri y P. leucoptera). Peropteryx pallidoptera fue recientemente descrita y se distribuye en los bosques de tierras bajas amazónicas de Ecuador, Perú, Brasil y Colombia. En esta nota, se reporta el primer registro de P. pallidoptera en Bolivia. El 22 de noviembre de 2016 , se observó una colonia de murciélagos en una cavidad en el suelo, en un parche de bosque ubicado en la comunidad rural de Isinuta en la Provincia Chapare (Departamento de Cochabamba). El área está clasificada como ecorregión de bosques del sudoeste de la Amazonía. Se colectó uno de los murciélagos y confirmamos la identificación de la especie con medidas del cráneo. Se observaron todos los caracteres diagnósticos externos y craneales de P. pallidoptera en el ejemplar. Además, las medidas externas y craneales están dentro del rango reportado para la especie. Este ejemplar extiende la distribución conocida de P. pallidoptera 1,420 km al sureste desde el punto más cercano en Perú, y es la localidad más austral de la especie. El hábitat y refugio donde se colectó $P$. pallidoptera concuerda con lo descrito en la literatura. El nuevo registro en Bolivia se encuentra dentro de la amplia distribución potencial en la región amazónica predicha en la descripción de la especie. Sin embargo, crea una gran brecha en el norte de Bolivia, el noroeste de Brasil y el sureste de Perú, donde se espera tener más registros en el futuro.

Palabras clave: Cochabamba; extensión de rango; murciélago cara de perro de alas pálidas; región Amazónica; registro más austral.

๑ 2021 Asociación Mexicana de Mastozoología, www.mastozoologiamexicana.org

The genus Peropteryx Peters, 1867 (Emballonuridae) contains five species (Simmons and Cirranello 2020) distributed in the Neotropical region. Three of these species have been reported in Bolivia: P. macrotis, P. kappleri, and P. leucoptera (Aguirre et al. 2019; Poma-Urey et al. 2021). Peropteryx pallidoptera is a recently described species (Lim et al. 2010) that is distributed in the Amazonian lowland forests below $400 \mathrm{~m}$ of Ecuador, Perú, Brazil, and Colombia (Solari 2016). This distribution is known from 34 specimens collected in 10 localities (Lim et al. 2010; McDonough et al. 2010; Díaz 2011; Castro et al. 2012; Suarez-Castro et al. 2012; Guerra and Albuja 2012; Morales-Martínez 2013; Medina et al. 2015; Wilson and Mittermeier 2019). Peropteryx pallidoptera is included in the IUCN red list of threatened species as
Data Deficient due to the few known collecting localities, apparently all restricted to one unique ecoregion (Solari 2016). We report the first individual of P. pallidoptera collected in Bolivia, which now represents the southernmost locality of the species.

We collected our specimen in the rural community of Isinuta Nueva América ( $16^{\circ} 42^{\prime} 50.94^{\prime \prime} \mathrm{S}, 65^{\circ} 40^{\prime} 4.98^{\prime \prime} \mathrm{W}$, 260 m), Chapare Province, Cochabamba Department, Bolivia. The area is located between the rivers Isinuta to the south, and Isiboro to the north. The site is near the southern border of the indigenous protected area Territorio Indígena y Parque Nacional Isiboro-Sécure (TIPNIS, by its initials in Spanish). Also, it is $0.5 \mathrm{~km}$ west from the secondary road under construction that will connect the departments of 
Cochabamba and Beni. According to Ibisch et al. (2003), the area is classified as southwestern Amazonian forests ecoregion, and Isinuta is in the limit between Subandean and Preandean forests subecoregions, which are the transition from the montane forests of the Andes (Yungas ecoregion) to the Amazon lowland forests. The average annual temperature in the Preandean forest subecoregion is $24-28^{\circ} \mathrm{C}$, the average annual precipitation is $1,300->7,000 \mathrm{~mm}$, with a maximum of 2 dry months, the landscape is dominated by moderate hills, and the vegetation is mostly evergreen rainforest disturbed by agricultural use (lbisch et al. 2003).

The collecting locality is in a patch of forest where the terrain is hilly ( $4-8 \mathrm{~m}$ high) and, under the trees, we found small cavities supported by plant roots where the soil was clayey and reddish yellow. The cavities were usually $1 \mathrm{~m}$ tall; some were very deep, and others were shallow. On November 22, 2016, we observed a colony of bats in a root cavity (Figure 1a) and we manually captured two females with translucent wings. We collected one of the bats (subadult) following the guidelines by Sikes et al. (2016), and we measured and released the other bat (pregnant female). External measurements recorded in the field were: total length (TL), tail length $(T)$, hind foot length $(H F)$, ear length (E), and forearm length (FA) in millimeters, and weight (W) in grams. We stored the specimen in alcohol and deposited it at the Museo de Historia Natural Alcide d'Orbigny (Cochabamba, Bolivia; MHNC-M 555). To confirm identification, we extracted and cleaned the skull, and measured it with a digital caliper to the nearest $0.01 \mathrm{~mm}$. Cranial measurements taken were: greatest length of skull (GLS), condyloin-
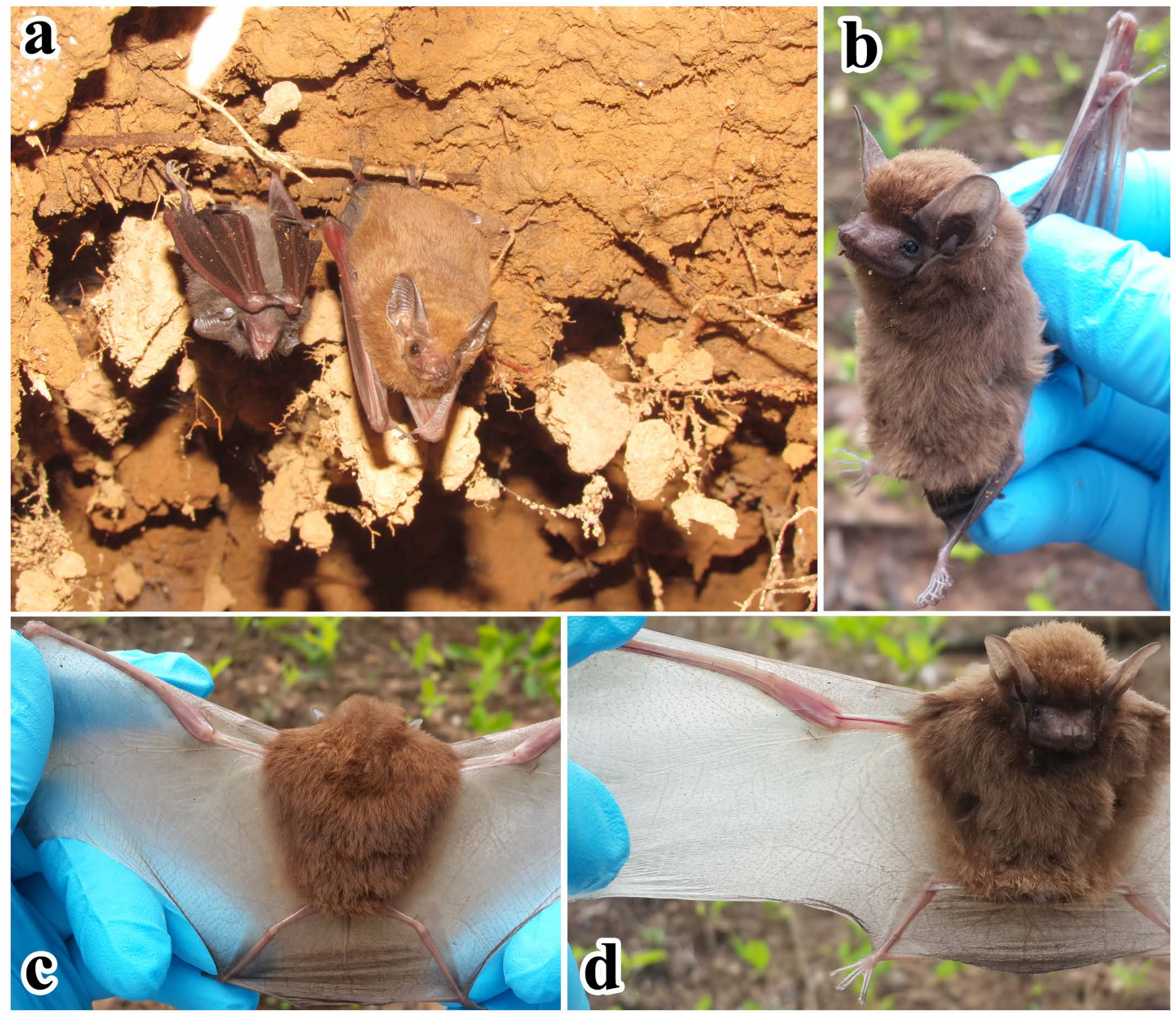

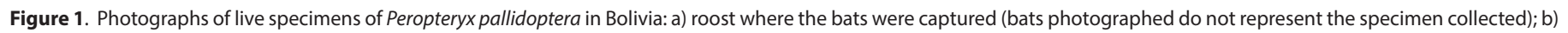

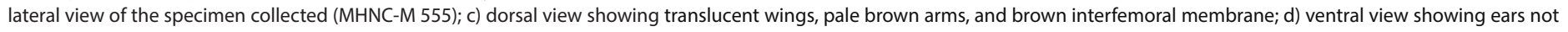

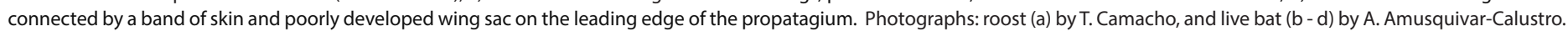


cisive length (CIL), zygomatic breadth (ZB), mastoid breadth $(\mathrm{MB})$, breadth of braincase (BBC), postorbital constriction (POC), maxillary toothrow length (CM3), and breadth across molars (M3M3) in millimeters. Measurements reported by other authors were compiled and differentiated by sex and country in Table 1: Peruvian specimens were obtained from Lim et al. (2010) and Díaz (2011), Ecuadorian specimens from Lim et al. (2010), McDonough et al. (2010) and Guerra and Albuja (2012), Brazilian specimen from Castro et al. (2012), and Colombian specimens from Suarez-Castro et al. (2012) and Morales-Martínez (2013). It is noteworthy that in some cases the authors reported the condylobasal length and not the condyloincisive length, and thus these measurements were not included.

We observed all external diagnostic characters of P. pallidoptera described by Lim et al. (2010) in our specimen (Figure $1 b-1 d)$ : translucent wings from the tip to the elbow and evenly colored with a tinge of brown, pale brown arms and digits, and ears not connected by a band of skin. Our specimen also presented all cranial diagnostic characters: the rostrum is not broad (Figure 2a), the lateral pterygoid pits are narrow and shallow, and separated by the mesopterygoid extension (Figure 2b), and the upper anterior premolar is tiny and peglike (Figure 2c).

Other morphological characters we observed in the specimen also coincide with the description: long dorsal brown fur with pale hair bases, pale ventral hair, brown ears, brown interfemoral membrane, a poorly developed wing sac on the leading edge of the propatagium (Figure $1 \mathrm{~b}-1 \mathrm{~d})$, slender postorbital processes, and a rostrum not dorsally inflated. The only difference we observed was that our specimen had translucent wings that included the propatagium and plagiopatagium, on the sides of the body, when the bat was alive, which is similar to the report

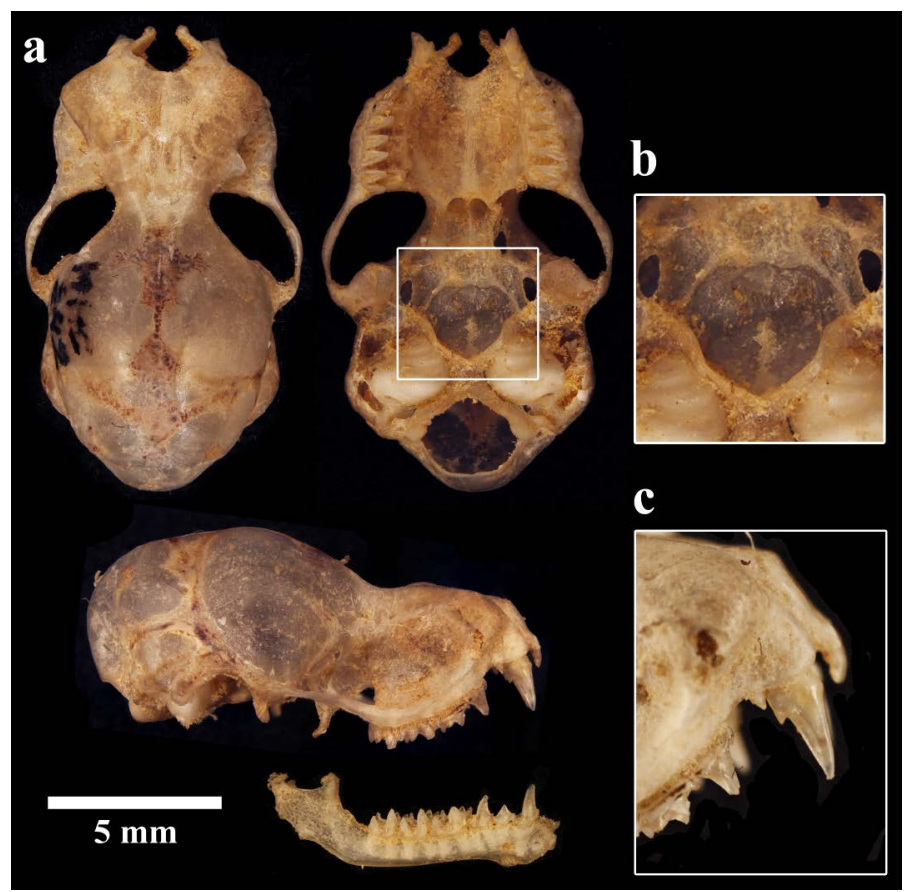

Figure 2. Cranial photographs of the voucher specimen of Peropteryx pallidoptera (MHNC-M 555) in Bolivia: a) dorsal, ventral, and lateral views of the skull of the specimen; b) detail of the narrow and shallow lateral pterygoid pits separated by the mesopterygoid extension anteriorly and the basisphenoid pit; c) detail of the upper anterior premolar, which is tiny and peglike. Photographs: G. Callapa.

by Castro et al. (2012). It is noteworthy that the digits and feet turned white in the alcohol preserved specimen.

The external and cranial measurements are within the range reported in the description and for other individuals (females) collected in Perú, Ecuador, Brazil, and Colombia (Table 1). Our specimen extends the known distribution of P. pallidoptera $1,420 \mathrm{~km}$ to the southeast from the nearest point in Perú reported by Medina et al. (2015). It is currently the southernmost locality for the species (Figure 3).

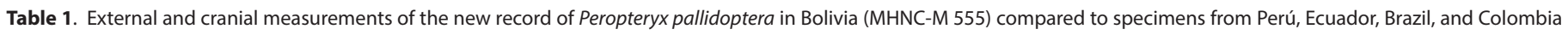
reported in the literature. The range is followed by number of individuals in parenthesis. The abbreviations and sources are specified in the text.

\begin{tabular}{|c|c|c|c|c|c|c|c|c|}
\hline \multirow[b]{2}{*}{ Sex } & \multirow{2}{*}{$\begin{array}{c}\text { Bolivia } \\
q\end{array}$} & \multicolumn{2}{|c|}{ Perú } & \multicolumn{2}{|c|}{ Ecuador } & \multirow{2}{*}{$\begin{array}{c}\text { Brazil } \\
q \\
\end{array}$} & \multicolumn{2}{|c|}{ Colombia } \\
\hline & & $q$ & $\widehat{0}$ & q & 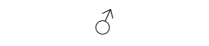 & & q & $\hat{o}$ \\
\hline $\mathrm{TL}$ & 55 & $58-67(18)$ & 62 & $43.8-55(2)$ & $44.6-57(4)$ & 55 & $52-53.5(2)$ & 54 \\
\hline $\mathrm{T}$ & 10 & $11-14(18)$ & 11 & $12-13(2)$ & $8.6-15(4)$ & 12 & $9.6-12(2)$ & 12 \\
\hline $\mathrm{HF}$ & 8 & $8-10(18)$ & 9 & $6.5-7(2)$ & $6.6-9(4)$ & 9 & $7.4-10(2)$ & 8 \\
\hline$E$ & 16 & $14-17(18)$ & 15 & $11.5-14.5(2)$ & $9-15(4)$ & 15 & $13.4-14(2)$ & 13 \\
\hline FA & 41.28 & $40.21-43(14)$ & 39 & $39.5-42(2)$ & $37.5-41.2(4)$ & 42.96 & $37-37.1(2)$ & 40 \\
\hline W & 6 & $4.5-6(15)$ & 4.3 & $3-4.7(2)$ & $4-6(4)$ & 5 & - & - \\
\hline GLS & 13.73 & $13.46-14.10(8)$ & - & 13.50 & $13.50-14.10(3)$ & 14.16 & $13.70-13.74(2)$ & 13.60 \\
\hline $\mathrm{CIL}$ & 12.38 & $12.20-12.86(8)$ & - & - & 12.5 & 12.36 & 12.40 & 12.00 \\
\hline ZB & 8.43 & $8.00-8.70(9)$ & 8.10 & 7.90 & $7.90-8.20(3)$ & 8.54 & $7.90-8.39(2)$ & - \\
\hline MB & 7.27 & $6.90-7.45(9)$ & 7.20 & 6.90 & $6.80-7.30(3)$ & 7.10 & $6.90-7.40(2)$ & 7.10 \\
\hline BBC & 6.66 & $6.30-6.76(9)$ & 6.50 & 6.50 & $6.40-6.80(3)$ & 6.58 & $6.20-6.36(2)$ & 6.30 \\
\hline POC & 2.60 & $2.60-2.91(9)$ & $2.60-2.90(2)$ & 2.40 & $2.60-2.80(3)$ & 2.86 & $2.40-3.00(2)$ & 2.20 \\
\hline CM3 & 5.41 & $5.00-5.50(9)$ & $5.00-5.20(2)$ & 5.20 & $5.10-5.30(3)$ & 5.56 & $5.33-5.4(2)$ & 5.40 \\
\hline M3M3 & 5.97 & $5.70-6.59(9)$ & $5.80-5.90(2)$ & 5.70 & $5.90-6.10(3)$ & 6.34 & 6.00 & 5.90 \\
\hline
\end{tabular}




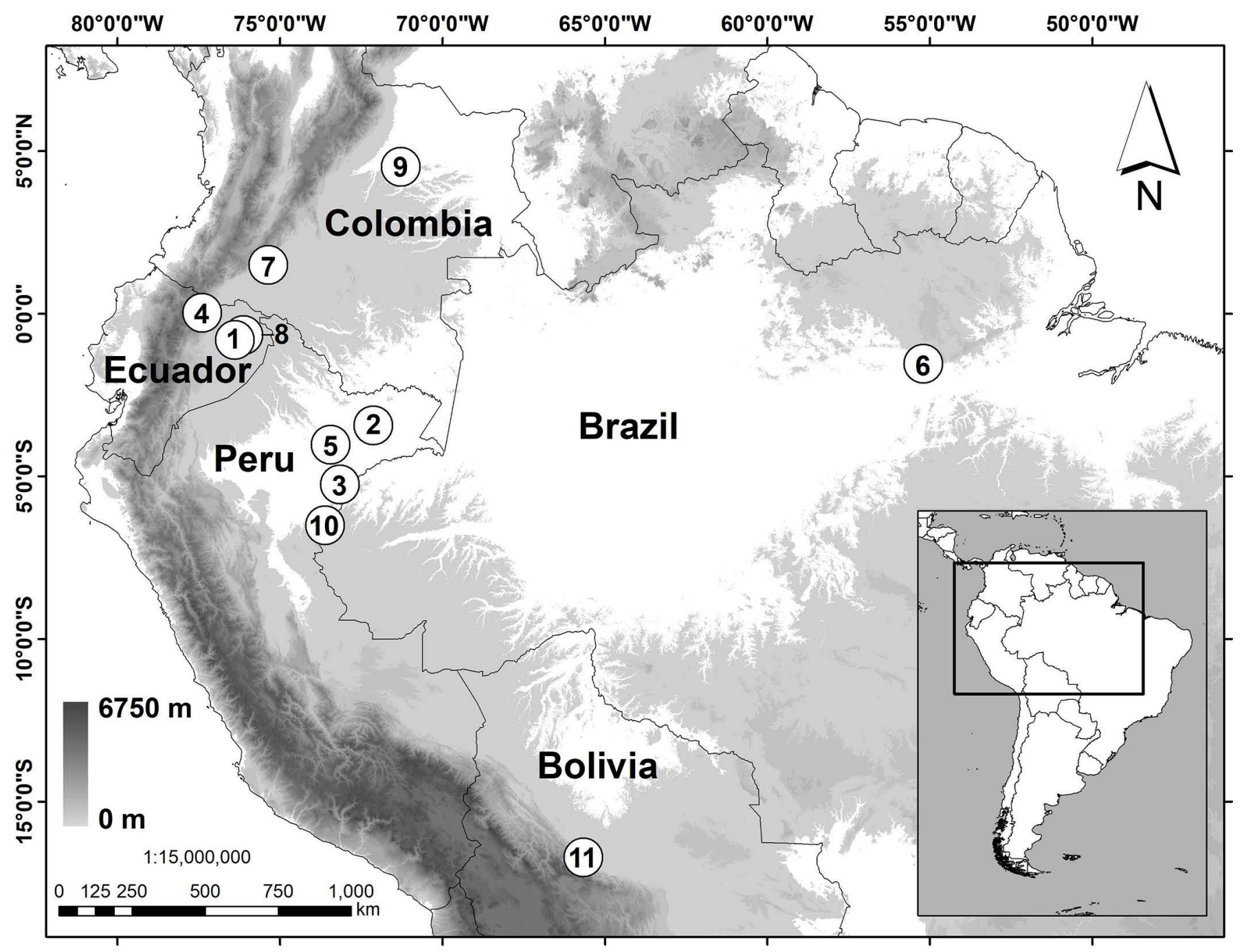

Figure 3. Map of the collecting localities of Peropteryx pallidoptera reported to date: 1) Ecuador, Orellana, $66 \mathrm{~km} \mathrm{~S}$ of Pompeya Sur $\left.00^{\circ} 48^{\prime} \mathrm{S}, 76^{\circ} 24^{\prime} \mathrm{W} ; 2\right)$ Perú, Loreto, Amazon River, Orosa $03^{\circ} 26^{\prime} \mathrm{S}, 72^{\circ} 08^{\prime} \mathrm{W}$; 3) Perú, Loreto, Rio Galvez, Nuevo San Juan $05^{\circ} 14^{\prime} 50^{\prime \prime} \mathrm{S}, 73^{\circ} 09^{\prime} 50^{\prime \prime} \mathrm{W}$ (19 specimens, Lim et al. 2010); 4) Ecuador, Bosque del Aguarico, $20 \mathrm{~km}$ from Lumbaqui $00^{\circ}$ $2^{\prime} 4.17^{\prime \prime} \mathrm{N}, 71^{\circ} 24^{\prime} 13.93^{\prime \prime} \mathrm{W}$ (1 specimen, McDonough et al. 2010); 5) Perú, Loreto, San Juan, Camino a El Paujil, $1.8 \mathrm{~km}$ al W del km 35 de la carretera lquitos-Nauta $4^{\circ} 01.217^{\prime} \mathrm{S}, 73^{\circ} 26.787^{\prime} \mathrm{W}$ (5 specimens, Díaz 2011); 6) Brazil, Pará, Curuá, Mamiá Village, farm Mangal 1³2' 14.7" S, 55 12' 30.1"W (1 specimen, Castro et al. 2012); 7) Colombia, Caquetá, Montañita, vereda Las Juntas, hacienda Las Delicias, quebrada El Oso, cueva La Virgen $01^{\circ} 30^{\prime} 9.6^{\prime \prime} \mathrm{N}, 75^{\circ} 22^{\prime} 5.9^{\prime \prime} \mathrm{W}$ ( 2 specimens Suarez-Castro et al. 2012); 8) Ecuador, Cueva Yasuní 1, a $1 \mathrm{~km}$ de la margen derecha del

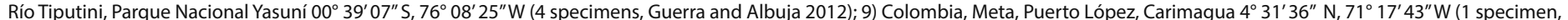
Morales-Martínez 2013); 10) Perú, Loreto, Cabeceras de Qda. Lobo, Zona Reservada Sierra del Divisor, Distrito Tapiche, Provincia Requena $6^{\circ} 30^{\prime} 27.6^{\prime \prime} \mathrm{S}, 73^{\circ} 37^{\prime} 26.1^{\prime \prime} \mathrm{W}(1 \mathrm{specimen,} \mathrm{Medina}$ et al. 2015); 11) Bolivia, Cochabamba, Isinuta Nueva America, Provincia Chapare $16^{\circ} 42^{\prime} 50.94^{\prime \prime} \mathrm{S}, 65^{\circ} 40^{\prime} 4.98^{\prime \prime} \mathrm{W}$ (1 specimen, this study). Gray scale indicates range of elevation from $0 \mathrm{~m}$ (white) to 6,750 m (dark gray). Design: M. Ocampo.

Peropteryx pallidoptera is known to occupy a variety of roosts: in animal burrows or holes, cavities in fallen trees, foliage, under fallen trees, and cavities roofed by roots and soil along the margins of water bodies (Lim et al. 2010; Voss et al. 2016). The type of roost we observed in the locality of Isinuta is consistent with the description of a hole in the ground supported by roots (Figure 1a). Similarly, the habitat type where we caught our specimen shares the same characteristics where most specimens have been previously reported, i.e. lowland rainforest, below $400 \mathrm{~m}$, that receives more than $2,800 \mathrm{~mm}$ of annual precipitation (Lim et al. 2010). Consequently, our new record in Bolivia is not surprising and supports the potential wide distribution in the Amazon region proposed by Lim et al. (2010). Our record in Bolivia constitutes a remarkable distribution extension of $P$. pallidoptera, by $1,420 \mathrm{~km}$ southeast from the nearest collecting locality in Perú. It is the southernmost collecting locality to date, and it creates a large gap in the Amazonian region of Bolivia, northwestern Brazil, and southeastern Perú where more records should be expected in the future.

\section{Acknowledgements}

The Rufford Foundation financed the fieldwork for the project "Andean Forest Conservation and Small Mammals in Bolivia" lead by MH-C. We thank the community of Isinuta Nueva América, especially A. García Tenorio, his wife Romualda, and his family for all the support in the study site. We also thank M. Ocampo for the map design, and G. Callapa for the skull photographs. The Plurinational State of Bolivia provided research and collecting permissions CAR/ MMAyA/VMABCCGDF/UVSAPN1080/2015. 


\section{Literature cited}

Aguirre, L. F., T. Tarifa, R. B. Wallace, N. Bernal, L. Siles, E. Aliaga-Rossel, and J. Salazar-Bravo. 2019. Lista actualizada y comentada de los mamíferos de Bolivia. Ecología en Bolivia 54:1-41.

Castro, I. J., E. R. Santos, A. C. M. Martins, D. Dias, and A. L. Peracchi. 2012. First record of the pale-winged dog-like bat Peropteryx pallidoptera (Chiroptera: Emballonuridae) for Brazil. Mammalia 76:451-453.

Díaz, M. 2011. New records of bats from the northern region of the Peruvian Amazon. Zoological Research 32:168-178.

GuerRa, M. J., AND L. Albuja. 2012. Registros adicionales de tres especies de murciélagos en el Yasuní, Amazonía ecuatoriana. Revista Politécnica 30:166-171.

Ibisch, P. L., S. G. Beck, B. Gerkmann, and A. Carretero. 2003. Ecoregiones y ecosistemas. Pp. 47-88 in Biodiversidad: la riqueza de Bolivia (Ibisch, P. L., and G. Mérida, eds.). Editorial Fundación Amigos de la Naturaleza. Santa Cruz, Bolivia.

Lim, B. K., M. D. Engstrom, F. A. Reid, N. B. Simmons, R. S. Voss, AND D. W. Fleck. 2010. A new species of Peropteryx (Chiroptera: Emballonuridae) from western Amazonia with comments on phylogenetic relationships within the genus. American Museum Novitates 3686:1-20.

McDonough, M. M., B. K. Lim, A. W. Ferguson, C. M. Brown, S. F. Burneo, and L. K. Ammerman. 2010. Mammalia, Chiroptera, Emballonuridae, Peropteryx leucoptera Peters, 1867 and Peropteryx pallidoptera Lim, Engstrom, Reid, Simmons, Voss and Fleck, 2010: Distributional range extensions in Ecuador. Check List 6:639-643.

Medina, C. E., E. López, K. Pino, A. Pari, and H. Zeballos. 2015. Biodiversidad de la zona reservada Sierra del Divisor (Perú): una visión desde los mamíferos pequeños. Revista Peruana de Biología 22:199-212.

Morales-Martínez, D. M. 2013. Primer registro de Peropteryx pallidoptera (Chiroptera: Emballonuridae) en ecosistemas de Sabana. Therya 4:401-407.

Poma-Urey, J. L., L. H. Acosta, M. R. Ingala, S. G. Revollo, M. A. Meza, S. Gutiérrez-Cruz, J. C. Zabala-Pedraza, M. Peñaranda, and J. Salazar-Bravo. 2021. Nueva especie de Peropteryx (Chiroptera: Emballonuridae) para Bolivia. Notas sobre Mamíferos Sudamericanos 3:e21.2.5.

Sikes, R. S., the Animal Care and Use Committee of the American Society of Mammalogists. 2016. 2016 Guidelines of the American Society of Mammalogists for the use of wild mammals in research and education. Journal of Mammalogy 97:663-688.

Simmons, N. B., and A. L. Cirranello. 2020. Bat Species of the World: A taxonomic and geographic database. Available at https://www.batnames.org. Accessed on December $17,2020$.

Solari, S. 2016. Peropteryx pallidoptera. The IUCN Red List of Threatened Species 2016: e.T85822291A85822446. https://dx.doi.org/10.2305/IUCN.UK.2016-3.RLTS. T85822291A85822446.en. Downloaded on December 22, 2020.

Suarez-Castro, A., H. E. Ramírez-Chaves, M. E. Rodríguez-PosaDA, AND J. GaRcía. 2012. New records of Peropteryx leucoptera and first record of Peropteryx pallidoptera (Chiroptera-Emballonuridae) from Colombia. Mastozoología Neotropical 19:165-171.
Voss, R. S., D. W. Fleck, R. E. Strauss, P. M. Velazco, and N. B. Simmons. 2016. Roosting ecology of Amazonian bats: evidence for guild structure in hyperdiverse mammalian communities. American Museum Novitates 3870:1-43.

Wilson, D. E., And R. A. Mittermeier. 2019. Handbook of the Mammals of the World, Volume 9 - Bats. Lynx Editions. Barcelona, Spain.

Associated editor: Cristian Kraker-Castañeda Submitted: January 27, 2021; Reviewed: April 6, 2021. Accepted: April 14, 2021 ; Published on line: May 1, 2021. 